\title{
Physisporinus vitreus: a versatile white rot fungus for engineering value-added wood products
}

\author{
Francis W. M. R. Schwarze • Mark Schubert
}

Received: 3 June 2011 /Revised: 28 July 2011 / Accepted: 5 August 2011 /Published online: 8 September 2011

(C) Springer-Verlag 2011

\begin{abstract}
The credo of every scientist working in the field of applied science is to transfer knowledge "from science to market," a process that combines (1) science (fundamental discoveries and basic research) with (2) technology development (performance assessment and optimization) and (3) technology transfer (industrial application). Over the past 7 years, we have intensively investigated the potential of the white rot fungus, Physisporinus vitreus, for engineering value-added wood products. Because of its exceptional wood degradation pattern, i.e., selective lignification without significant wood strength losses and a preferential degradation of bordered pit membranes, it is possible to use this fungus under controlled conditions to improve the acoustic properties of tonewood (i.e., "mycowood") as well as to enhance the uptake of preservatives and wood modification substances in refractory wood species (e.g., Norway spruce), a process known as "bioincising." This minireview summarizes the research that we have performed with $P$. vitreus and critically discusses the challenges encountered during the development of two distinct processes for engineering value-added wood products. Finally, we peep into the future potential of the bioincising and mycowood processes for additional applications in the forest and wood industry.
\end{abstract}

Keywords Physisporinus vitreus $\cdot$ Bioincising ·

Mycowood - Wood permeability · Acoustic properties .

Tonewood $\cdot$ Value-added wood products

F. W. M. R. Schwarze $(\bowtie) \cdot$ M. Schubert

Wood Protection \& Biotechnology Wood Department,

Empa Swiss Federal Laboratories for Materials

Testing and Research,

Lerchenfeldstrasse 5,

CH-9014 St. Gallen, Switzerland

e-mail: francis.schwarze@empa.ch

\section{Introduction}

Using wood decay fungi for biotechnological applications in the forest products industry has been studied for several decades because the specificity of their enzymes and the mild conditions under which degradation proceeds make them potentially suitable agents for wood modification (Majcherczyk and Hüttermann 1988; Messner et al. 2002; Schwarze 2008). For example, fungi are successfully used in the biopulping or biobleaching of kraft pulp (Mai et al. 2004) or in bioremediation and detoxification of preservative-treated waste wood because of their tolerance and ability to degrade creosote, toxic polyaromatic hydrocarbon compounds, and pentachlorophenol (Shuen and Buswell 1992; Cerniglia 1997; Samson et al. 1998; Richter et al. 2003; Mai et al. 2004). The alterations in the woody cell wall structure reflect the plasticity of the degradation modes of wood decay fungi and can be used for the purpose of wood engineering (Deflorio et al. 2005; Schwarze 2007, 2008). During the early 1960s, industrially cultivated white rot fungus (Trametes versicolor L.) was used in the German Democratic Republic, mainly on beech wood for pencil or ruler production (i.e., "mykowood," Unbehaun et al. 2000; Mai et al. 2004).

More recently, we have investigated the potential of a range of wood decay fungi for biotechnological applications in the forest product industry. In Switzerland, 65\% of the forest stand consists of Norway spruce [Picea abies (L.) Karst.] and European silver fir (Abies alba Mill.). The wood of either of these species to be used outdoors requires preservative treatment, which involves impregnating the wood cells with chemical preservatives or wood modification substances to suppress colonization by wood decay fungi. In most cases, the substance is infused into the wood cells using vacuum pressure impregnation, but the wood of 
difficult-to-treat (refractory) species such as $P$. abies and $A$. alba must be incised to enhance the uptake and distribution of the chemicals in the wood. Incising is a pretreatment process in which small incisions, or slits, are made in the wood surface to increase the exposed end and side grain surface area (Hernandez and Winandy 2005). "Bioincising" is a biotechnological process that has been developed to improve the permeability of refractory wood species by incubation under controlled conditions for short periods with a white rot fungus, Physisporinus vitreus. Our studies show that isolates of $P$. vitreus have an extraordinary capacity to induce substantial permeability changes in the heartwood of $P$. abies without causing significant loss of impact bending strength (Schwarze and Landmesser 2000; Schwarze et al. 2006, 2007; Lehringer et al. 2009). In fact, wood durability of $P$. abies and A. alba is enhanced by the bioincising process, which is a promising technology for efficiently distributing wood modification substances, promoting desired improvements in wood properties, as well as leaving the wood surface aesthetically pleasing and the mechanical wood properties unaltered (Lehringer et al. 2011). Another application of the controlled use of the degradation pattern of $P$. vitreus is the production of mycowood with improved acoustic properties to overcome the shortages of natural wood with the superior tonal qualities desired by traditional musical instrument makers.
The objective of this minireview is to summarize the work that has been conducted to implement the ambitious goal of transferring a standardized biotechnology process using $P$. vitreus from "science to market" (Fig. 1). The fundamental discoveries and basic research conducted on $P$. vitreus are the science; characterization of fungal activity, the performance assessment of fungally modified wood, and optimization of the process comprise the development of the technology; and the benefits of applying the bioincising and mycowood processes for the forest and wood industry (i.e., technology transfer) are all discussed in detail.

\section{Science}

Bioincising: improving the permeability of refractory wood species dollars

$P$. vitreus is a basidomycete (Polyporales, Meripilaceae) that belongs to the large and puzzling Polyporus lignosus complex. It can be very easily confused with Poria nigrescens and Physisporinus sanguinolenta, but is most easily distinguished by its characteristic decay, a conspicuous white pocket rot. When fresh, the basidiocarp appears much like $P$. sanguinolenta, which differs in usually turning reddish where bruised and on drying and in having

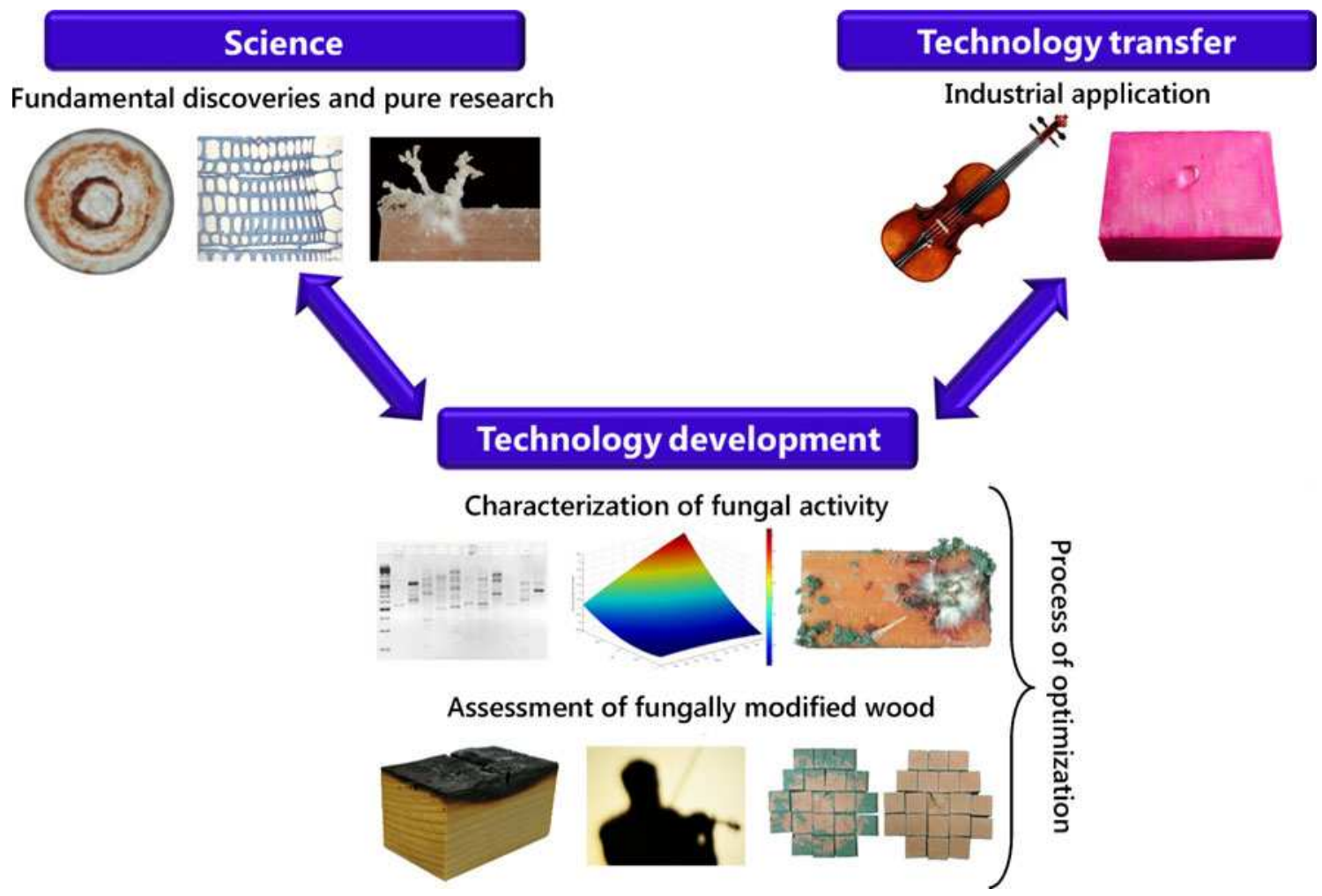

Fig. 1 Steps required for implementation of the "bioincising" and "mycowood" process and steps involved in technology transfer 
somewhat larger pores. P. sanguinolenta var. expallescens, however, is so similar that in the absence of decayed wood, a clear distinction is difficult. $P$. vitreus occurs on angiosperms and more rarely on gymnosperms, in the USA apparently more abundant southward, but known from Ontario southward in eastern North America to Missouri, in Alaska, Idaho, British Columbia, Washington, Puerto Rico, Europe, and New Zealand.

Interestingly, $P$. vitreus decomposes water-saturated timber in cooling towers by a fibrous, white pocket rot (Van Acker et al. 1995; Schmidt et al. 1996, 1997; Schmidt 2007). In the laboratory, the fungus reveals a remarkable pattern of colonization. In crosswise piled water-saturated pine wood, the fungus decomposes only those parts of the substrate not surrounded by air (Schmidt et al. 1996, 1997). Some isolates of this fungus have an extraordinary capacity to induce significant permeability changes in the heartwood of Norway spruce and silver fir after hydrolysis of bordered pit membranes without causing significant loss of wood strength (Schwarze et al. 2006). The effects of treating conifer wood with commercial pectinases or bacteria to improve penetration of preservatives have been studied in detail (Nicholas and Thomas 1968; Bauch et al. 1970; Johnson 1979; Sharma and Kumar 1979; Mai et al. 2004). Commercial pectinase treatment improves the penetration of preservative into the sapwood of Douglas fir by opening pit apertures, as long as the treatment is combined with either a low $\mathrm{pH}$ or a calcium chelator such as ammonium oxalate or sodium hexametaphosphate (Tschernitz 1973). The most effective, tested on finely ground wood of Norway spruce, is hydrolases with a broad spectrum of cellulolytic and hemicellulolytic activity (Militz 1993a, b). But the application of these enzymes has failed to enhance the permeability of solid wood to any useful extent, both because of the slowness of their diffusion into the wood and the effect of extractives, which adhere to aspirated pits and make them resistant to decomposition (Militz 1993a, b).

Our studies show that isolates of $P$. vitreus have an extraordinary capacity to induce substantial permeability changes in heartwood of $P$. abies without causing significant loss of impact bending strength (Schwarze and Landmesser 2000; Schwarze et al. 2006; Schwarze 2007; Lehringer et al. 2009). Even after 6 weeks incubation, when the mass loss induced by $P$. vitreus was slight $(>1 \%)$, wood permeability increased to approximately $300-400 \mathrm{~kg} \mathrm{~m}^{-3}$ in Norway spruce and $400-680 \mathrm{~kg} \mathrm{~m}^{-3}$ in silver fir (Schwarze et al. 2006). Conspicuous, qualitative changes in permeability were also apparent from the uptake of the bluish dye Neolan Glaucin E-A. Uptake of the dye within test blocks of silver fir incubated with $P$. vitreus was visually homogeneous but less so in Norway spruce (Schwarze et al. 2006). FE-REM studies revealed that uptake of Neolan Glaucin E-A was attributable to degradation of pit membranes (Fig. 2).
Complete or partial hydrolysis of bordered pits and crossfield pits in regions of the wood that were stained with Neolan Glaucin E-A was apparent, whereas in unstained regions, the pit membranes were intact (Fig. 2, Schwarze et al. 2006). The hyphae entered the pit chamber via the apertures, and the membranes were subsequently degraded (Fig. 2). Degradation commenced from the thickened, central part of the membrane (the torus). Calcium oxalate crystals were regularly observed on the hyphae (Fig. 2), and in the wood of A. alba, they often accumulated within bordered pits in close proximity to the hyphae (Fig. 2). We will discuss how we optimized the uniformity of wood colonization and the duration of incubation, in order to improve the permeability of water-borne wood preservatives or wood modification agents applied by brushing, dipping, and impregnation, under the "Technology development" section below.

The P. vitreus strain (Empa No. 642) used in all of our studies was assigned by PCR amplification and sequencing of the ITS1-5.8S-ITS2 region of the rDNA followed by alignment with published sequences using nucleotide BLAST (Begerow et al. 2010). The ITS1-5.8S-ITS2 sequence of the $P$. vitreus (Empa strain No. 642) was submitted to the EMBL databank under the following accession number: FM202494 (Schubert et al. 2009a).

Mycowood: improving the acoustic properties of wood for violins

An interesting field in which wood modification by $P$. vitreus can be used is the improvement of the acoustic properties of wood for contemporary violin making. Musical instruments produced by Antonio Stradivari during the late seventeenth and early eighteenth centuries are reputed to have superior tonal qualities than more recent instruments. Dendrochronological studies show that during his later decades, Stradivari used Norway spruce wood that had grown mostly during the Maunder Minimum (Topham and McCormick 2000; Burckle and Grissino-Mayer 2003), a period of reduced solar activity when relatively low temperatures caused trees to lay down wood with narrow annual rings, creating a high modulus of elasticity and low density (Esper et al. 2002). Traditionally, wood used in the manufacture of musical instruments is treated with primers, varnishes, or minerals to stiffen it. Such treatments can strengthen the adhesion between cell layers but increase the density and vibrating mass because the cells' lumina become occluded by the substance (Barlow et al. 1988; Schleske 1998, 2002a; Wegst 2006), which ultimately reduces the speed of sound. The increase in density has an adverse effect on the radiation ratio $[R=$ speed of sound $(c) /$ density $(\rho)]$, reducing the speed of sound and its resonance frequencies (Barlow et al. 1988; Schleske 
Fig. 2 a Transverse section of Norway spruce showing hyphal growth (arrows) and degradation of bordered pits (arrowheads). Bar $20 \mu \mathrm{m}$. b Scanning electron micrographs $(5 \mathrm{kV})$ showing bordered pits in A. alba after 6 weeks incubation with $P$. vitreus. The hyphae have entered the bordered pits via the aperture and degraded the torus; lysis (arrowhead) of the warty layer and calcium oxalate crystals (arrows) in close proximity to the hyphae within bordered pit chambers (arrows; a, b reproduced from Schwarze et al. (2006) by permission of deGruyter). Transverse section of untreated control (c) and Norway spruce wood after 12 weeks incubation with $P$. vitreus (d). $L$ cell lumen, $S w$ secondary wall, $\mathrm{Cml}$ compound middle lamella. Note that the delignification of secondary walls (arrowheads) commences the from hyphae (small arrows) growing within the cell lumen of tracheids (c, $\mathbf{d}$ reproduced from Schwarze et al. (2008) by permission of John Wiley and Sons, Inc.)
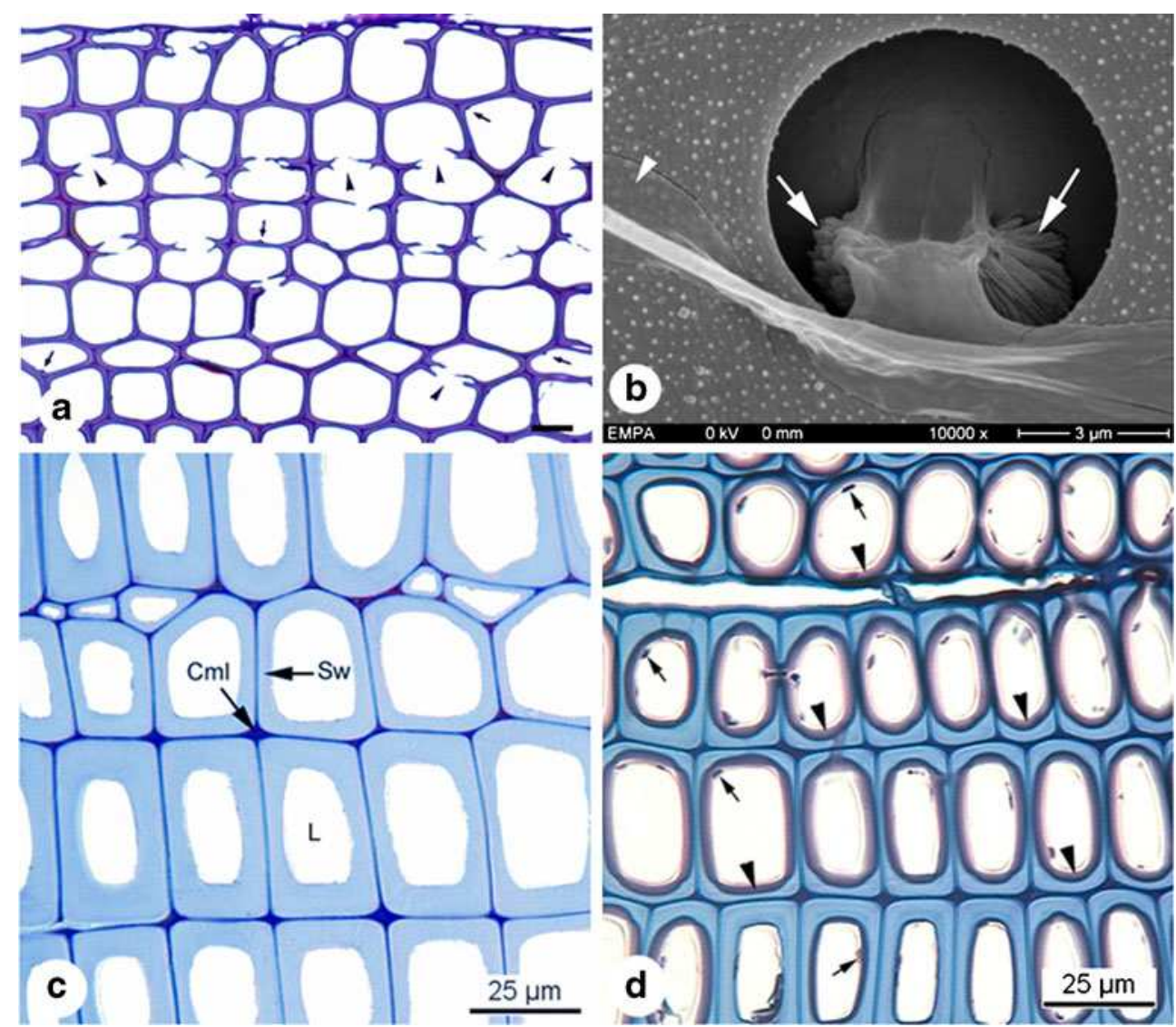

2002b; Spycher et al. 2008). Tests of other chemical treatments have shown that they increase the dynamic modulus of elasticity $\left(E_{\mathrm{L}}\right.$ and $\left.E_{\mathrm{R}}\right)$ and decrease the damping factor $\left(\delta_{\mathrm{L}}\right.$ and $\delta_{\mathrm{R}}$, Ono and Norimoto 1984; Yano et al. 1994; Meyer 1995), but although these treatments do not alter wood density, they increase the crystallinity of the cell wall, which is considered disadvantageous for wood processing (Yano et al. 1994). Other authors have suggested that the wood used by Guarneri and Stradivari to make the violins was chemically treated to kill woodworm and fungi (Nagyvary et al. 2006).

An alternative approach to improving the acoustic properties of wood is to reduce its density by fungal or bacterial degradation. During the seventeenth and eighteenth centuries, some degradation probably resulted from the practice of floating tree trunks in water (Gug 1991), but there is no evidence that this caused any noticeable reduction in wood density. According to Nagyvary (1988), the microbial degradation of pit membranes that occurred during this treatment would have resulted in an increase in wood permeability such that subsequent penetration of varnish would be enhanced. Recently, Wagenführ et al. $(2005 \mathrm{a}, \mathrm{b})$ used a new thermal treatment to improve the acoustic properties of resonance wood. Treatment at high temperatures results in a reduction in density because of decomposition of hemicellulose and cellulose, but $E$ is reduced. A negative side effect of heat treatment is that the material becomes brittle, causing problems during the manufacture of the instruments. Most of the described treatments alter the woody cell wall and adversely affect the properties of the compound middle lamellae, both of which have a pivotal role in determining the overall stiffness of wood.

In a homogeneous bulk material, ignoring surface effects, the speed of sound, $c$, is governed by two mechanical properties: $E$ and the density. In wood, which is strongly anisotropic, $c$ varies directionally and is decreased by any discontinuities in the compound middle lamella, such as those resulting from microbial degradation. Using the formulae shown in Table 1, it can be deduced that such degradation, even if very slight, results in an abrupt reduction in both $E$ and $c$ (Schwarze 1995) and has a negative impact on the acoustic properties of the wood. The compound middle lamella is penetrated or otherwise altered by most species of wood decay fungi, except for members of the Xylariaceae (e.g., Kretzschmaria deusta and Xylaria longipes), which have little ability to degrade guaiacyl (Nilsson et al. 1989; Schwarze 1995), found in very high concentrations in the compound middle lamella. As a result, this layer remains as an intact skeleton, even at a quite advanced stage of decay (Nilsson et al. 1989; Schwarze 1995; Schwarze 2007), which explains why the speed of 
Table 1 Principal acoustic properties used for the assessment of tonewood quality of axial (L) and radial (R) samples

\begin{tabular}{ll}
\hline Property & Assessment \\
\hline Density, $\rho\left(\mathrm{kg} / \mathrm{m}^{-3}\right)$ & $P$ for the specimens in L and R directions \\
Young's modulus of elasticity, $E(\mathrm{MPa})$ & $E$ for $\mathrm{L}$ and $\mathrm{R}$ directions \\
Speed of sound, $c\left(\mathrm{~m} / \mathrm{s}^{-1}\right)$ & $c=\sqrt{\frac{E}{\rho}}$ for $\mathrm{L}$ and $\mathrm{R}$ directions \\
Radiation ratio, $R\left(\mathrm{~m}^{4} / \mathrm{kg}^{-1} \mathrm{~s}^{-1}\right)$ & $R=\frac{c}{\rho}=\sqrt{\frac{E}{\rho^{3}}}$ for $\mathrm{L}$ and $\mathrm{R}$ directions \\
Damping factor $\delta_{\mathrm{L}}$ for L direction and $\delta_{\mathrm{R}}$ & $\delta=K \frac{\Delta f}{f_{\mathrm{r}}}$ where $f_{\mathrm{r}}$ is the resonance frequency, $\Delta f$ the \\
for R direction & associated damping, and $K$ is a coefficient that varies \\
& between $\frac{1}{\pi}$ and $\frac{\pi}{\sqrt{3}}$ \\
\hline
\end{tabular}

sound through the wood is little affected until that stage (Schwarze 1995; Schwarze 2007) and is the reason why decay caused by $K$. deusta is hard to detect in trees by means of acoustic devices (Schwarze 1995, 2004; Schwarze 2007).

Incubation of Norway spruce wood with $P$. vitreus causes marked density loss and cell wall thinning (Fig. 2); that is, the partly degraded wood resembled superior resonance wood grown under cold climate conditions. By assessing the incubated specimens microscopically and measuring five physical properties (Table 1), we found alterations in the wood structure that resulted in a reduction in density, accompanied by relatively little change in the speed of sound. After 20 weeks incubation, the wood had reduced in density by more than $10 \%$ and showed a concurrent increase in sound radiation, without any weakening of the structure (Schwarze et al. 2008). This finding is in good agreement with other research that shows that the gradual decomposition and loss of hemicellulose with time decreases wood density without affecting its Young's modulus, subsequently increasing the radiation ratio (Bucur 2006).

The increase in the radiation ratio of mycowood from "poor" to "good" puts it on a par with "superior" resonance wood grown in a cold climate (Schwarze et al. 2008). Moreover, differences in wood density between early and late growth were reduced, improving the vibrational efficacy and the production of sound similar to that of ancient violins. Norway spruce wood treated with wood decay fungi also damps sound more efficiently, giving it a more mellow timbre. The significant increase in the damping factor $(340 \%$ in the radial direction) that was recorded after 20 weeks incubation can be attributed partly to selective degradation of pit membranes.

\section{Technology development}

Process optimization by characterization of fungal activity and assessment of fungally modified wood

Despite initially promising results on small wood samples, the biotechnological use of wood decay fungi for modification of larger wood profiles and the transfer to industrial application displays particular challenges because of the variable performance of the fungus and the heterogeneity of the substrate. Highly efficient modification of wood by $P$. vitreus is based on optimal development of the mycelium, including the lag phase, hyphal elongation, and branching (Schubert et al. 2010a). Mycelial growth is greatly influenced by environmental conditions (Rayner and Boddy 1988), and the effect of the fungus is inextricably linked to the underlying substrate, wood, which is a complex anisotropic material with several hierarchical levels of organization from the macroscopic (e.g., growth rings), the mesoscopic (e.g., the set of wood cells) down to the microscopic, and nanoscopic scales (e.g., wood cells and fibrils). The interplay among the chemical composition of the substrate, its geometric structure, and the enzymatic activity influence the performance of $P$. vitreus and thus the outcome of the wood modification process. Successful upscaling of biotechnological processes in which $P$. vitreus is used to improve the substrate's properties requires a set of investigations to identify and quantify the important physical, chemical, and biological parameters and their sensitive control during fungal incubation. In addition to characterizing the fungal activity, the fungally modified wood has to be assessed, so an industry cooperation project was launched with the objective of scaling up the bioincising process using $P$. vitreus (CTI No. 8593.1).

Improving the effectiveness of wood modification by ensuring variable performance is minimized and development of the fungus is optimized requires identification of the principal parameters and understanding how these factors influence wood colonization by $P$. vitreus. The classical method of testing different factors involves varying the level of each parameter over a certain range, while maintaining the other test variables constant. This strategy is time consuming, requires a large number of experiments, and does not include interactive effects among the parameters on the process. To overcome these problems, we developed a radial basis function neural network and a response surface model for describing and predicting the lag phase and the specific growth rate of $P$. vitreus under combined effects of a range of parameters [i.e., temperature, water activity $\left(a_{\mathrm{w}}\right)$, and $\mathrm{pH}$ ] (Schubert et al. 2009a, 2010a). 
Our results show that temperature and $a_{\mathrm{w}}$, in particular, are key determinants of the development of $P$. vitreus, and pH plays a secondary role (Schubert et al. 2009a). The results are in good agreement with those of Griffin (1977) and Anagnost (2007), who maintain that most wood decay fungi are hydrophilic organisms $\left(a_{\mathrm{w}}>0.90\right)$ and require $a_{\mathrm{w}}$ to be at least 0.97. Furthermore, Schmidt et al. $(1996,1997)$ observed an extraordinarily strong dependence of $P$. vitreus on high moisture levels. They reported preferential colonization and degradation of water-saturated wood [wood moisture content (WMC) $>100 \%$ ] of Pinus sylvestris, P. abies, and Fagus sylvatica, with low air content. At WMC $>90 \%$, fungal growth within wood is normally impeded by a lack of oxygen, which highlights the remarkable biological capacity of $P$. vitreus to degrade timber in the special habitat of cooling towers. Taken together, these findings indicate that the amount of water available in the substrate (wood) is a very important factor for ensuring colonization and fungal growth by $P$. vitreus. Until the fiber saturation point (FSP) is reached, moisture in wood exists as bound or hygroscopic water within the cell wall because of hydrogen bonding of the hydroxyl groups mainly in the cellulose and hemicellulose (Schmidt 2007). At about the FSP, which ranges between $25 \%$ and $30 \%$ depending on the wood species, the content of bound water is maximal and free capillary water in liquid form is available in the cell lumen, as well in other voids in the woody tissue (Anagnost 2007; Schmidt 2007). To enable a short lag phase and high growth rate, superficial drying of wood must be avoided by setting low air flow around the wood and maintaining a high relative humidity.

In addition to abiotic parameters, biotic stress caused by other microorganisms influences the performance of $P$. vitreus. Therefore, the competitiveness and growth mode of $P$. vitreus against a range of blue stain fungi and Trichoderma species (challenge species) was investigated in dual culture tests and a spatially heterogeneous system of tessellation agar on different media. In addition, the robustness of wood colonization by $P$. vitreus against biotic influences was determined by controlled interaction tests with different inocula of a range of ascomycetes on Norway spruce heartwood (Schubert and Schwarze 2011). The selection of the challenge fungi was based on the fact that in pretests of wood incubation with $P$. vitreus, the selected fungi occurred as contaminants, or they are known to be wood-inhabiting pioneer colonizers (Rayner and Boddy 1988) or, in the case of Trichoderma spp., to have high antagonistic potential against basidiomycetes (Bruce and Highley 1991; Highley 1997; Highley et al. 1997). A comparison of the lag phase and growth rate of Trichoderma $\mathrm{sp}$. and $P$. vitreus revealed that even under optimal growth conditions, Trichoderma sp. showed a significantly shorter lag phase and higher growth rate (Schubert et al. 2009a, b, 2010a, b). Apart from their ability to overgrow and parasitize the mycelium, their high spatial and nutrient competitive abilities make Trichoderma spp. a decisive competitor of $P$. vitreus. Schubert and Schwarze (2011) also showed that Trichoderma spp. have by far the most significant negative effect on the performance of $P$. vitreus, even with a low inoculum potential. Synthesis of the results of the influence of abiotic and biotic parameters provides the basis for successful scaling up of the technologies and indicates that efficient heartwood modification by $P$. vitreus depends on optimal growth conditions as well as inhibiting contaminants, particularly competition by Trichoderma spp. during the lag phase of $P$. vitreus.

Intensive investigations to characterize fungally modified wood as well as to evaluate bioincised wood as an improved substrate for subsequent treatment with property-improving substances have been conducted (Lehringer et al. 2009, 2010, 2011; Lehringer 2011; Schubert et al. 2011a, b). Despite the higher uptake of wood modification agents after brushing or dipping and particularly after impregnation, a negative effect of bioincising on the target properties of the agents, regardless of the application method, has been found (Lehringer et al. 2009). Only the performance of bioicides is enhanced in bioincised wood (Schubert et al. 2011a, b). Lehringer et al. (2010) showed that under incubation conditions using a malt agar nutrient medium (narrow $C / N$ ratio of approximately 50/1), the colonization of the wood was very inhomogeneous and degradation of bordered pits was accompanied by cell wall degradation (selective delignification and hotspots of soft rot types I and II). These alterations in cell wall structure, particularly both types of soft rot, may be responsible for the enhanced flammability of bioincised wood. As Lehringer discusses in detail, a high nitrogen concentration (e.g., malt agar) seems to reduce the selective lignin degradation rate (Kirk et al. 1978) and additionally stimulates polysaccharide breakdown (Levi and Cowling 1969; Reid 1983; Dill and Kraepelin 1986). The occurrence of selective delignification and simultaneous degradation of lignin, cellulose, and hemicellulose were furthermore demonstrated by ultramicrospectrophotometry, Fourier transform infrared spectroscopy (Lehringer et al. 2011), and wet chemical analysis (Lehringer 2011). Vermiculite (wide $C / N$ ratio of approximately $400 / 1$ ) has been used in other studies (Schwarze and Landmesser 2000; Schwarze et al. 2008), and degradation of pit membranes only coincided with selective delignification of the tracheids without further cell wall damage.

Determining the enzymatic processes behind this heterogeneous decay pattern is still in progress. Screening of the enzymatic activity during wood degradation shows that $P$. vitreus apparently excretes small amounts of polygalacturonase. The lignolytic enzymes mangan peroxidase or lignin peroxidase were not detected, whereas laccase was produced and secreted by P. vitreus in high amounts (Ihssen 
et al. 2011). Interestingly, $P$. vitreus produces a particular laccase system with only one isoform. After purification, SDS-PAGE revealed the laccase has a mass of about $53 \mathrm{kDa}$, which is closer to a bacterial laccase $(40-60 \mathrm{kDa}$, Claus 2003) than to a fungal laccase $(60-80 \mathrm{kDa}$, Baldrian 2006). Furthermore, the ability to oxidize lignin model compounds according to the method of Kudanga et al. (2009) showed reduced reactivity of the laccase of $P$. vitreus in comparison with the commercially available laccase of $T$. versicolor (Sigma Aldrich) or that of Myceliophthora thermophile (Novozymes). Supposedly because of its specific enzyme composition, $P$. vitreus is a relatively weak lignolytic fungus that causes only small losses of mass during the incipient period of substrate colonization and it selectively delignifies the secondary walls without affecting the middle lamellae, even at advanced stages of degradation (Fig. 2).

Taking all important parameters (e.g., water activity, biotic stress, $C / N$ ratio) into consideration for optimal wood colonization, we developed an incubation system for $P$. vitreus in which all important parameters can be adjusted accordingly. With this incubation system, the required incubation time could be reduced significantly.

Genetic engineering could be a powerful approach to increasing productivity, minimizing unwanted effects, and optimizing the biotechnological use of filamentous fungi, but the challenge is establishing a suitable transformation method (Meyer 2008). Genetic manipulation of a fungus of interest requires the development of a plasmid-mediated transformation system that includes (1) infusion of exogenous DNA into recipient cells, (2) expression of genes present on the incoming DNA, and (3) stable maintenance and replication of the inserted DNA, leading to expression of the desired phenotypic trait (Ruiz-Diez 2002). Thus, to design an optimal engineering strategy, it is necessary to first identify the target property or negative side effect that should be increased or decreased, respectively. In the case of $P$. vitreus, identifying such a target property or side effect is very complicated because of the complex wood-fungus system.

Therefore, in a current project 205321-121701 funded by the Swiss National Science Foundation, we developed several visualization techniques (Stührk et al. 2010) and a fungal growth model for P. vitreus (Fuhr et al. 2010). By comparing the macro- and microscopic system properties obtained from computer simulations with results of laboratory experiments, we can improve our understanding on how a complex and difficult to observe system, such as fungus-wood, interacts under defined conditions.

However, the larger the dimensions of the incubated specimens, the higher the costs and the more difficult it is to maintain homogeneous colonization and to improve wood properties. Thus, according to the current state of knowl- edge, an application of the wood modification process for specialized niche products (e.g., tonewood or "mycowood") is maybe the most promising technology.

\section{Technology transfer}

Benefits of the bioincising and mycowood technologies for the forest and wood industry

Technology transfer does not mean simply movement or delivery; transfer can only happen if a technology is used. In other words, it is the application of knowledge and considered a process by which a technology developed for one purpose can be used in either a different application or by a new user.

One vision of high-technology wood preservation is the chemical modification of wood to render it impervious to natural degradation processes. Successful chemical modification of refractory wood species can only be accomplished if wood permeability is enhanced, which is the reason bioincising was developed. The estimated costs for the production of bioincised wood are currently approximately US $\$ 5,750$ per $\mathrm{m}^{3}$. The technology breakthrough in this area might not be the meeting of the economic criteria that would make it applicable to traditional markets for treated wood but rather the opening up of new markets for valueadded decorative products. Low maintenance, durable wood products have been clearly identified as having considerable market potential.

The best added value is derived from products that customers buy because they want them, not because they have to. More is paid for beauty than for practicality. In this context, musical instruments such as the violin are high-end products and a unique investment. Facing volatile equity markets, investors often look to gold and silver, but an updated study of classical instrument valuations by Graddy and Margolis (2010) shows that violins may be among the most stable of investments. Their data indicate that between 1850 and April 2009, the value of professional-quality instruments rose in real terms (i.e., after inflation) approximately 3\% annually. High-end violins have appreciated at much higher rates, particularly the rare instruments made by Italian masters such as Stradivari, Amati, and Guarneri del Gesù.

Since the beginning of the nineteenth century, Stradivarius violins have been compared with contemporary instruments made by other violin makers in so-called blind tests, the most serious of all probably being that organized by the BBC in 1974. In that test the world famous violinists Isaac Stern and Pinchas Zukerman, together with the English violin dealer Charles Beare, were challenged to identify blind the "Chaconne" Stradivarius made in 1725 , a "Guarneri del 
Gesu" of 1739, a "Vuillaume" of 1846, and a modern instrument made by the English master violin maker Roland Praill. The result was rather sobering; none of the experts were able to correctly identify more than two of the four instruments, and in fact, two of the jurors thought that the modern instrument was actually the "Chaconne" Stradivarius.

In a blind test at the Osnabrücker Baumpflegetage in 2009, the British star violinist Matthew Trusler played five different instruments behind a curtain so that the audience did not know which was being played. One of the violins Trusler played was his own "Strad," worth US \$2 million. The other four were all made by Michael Rhonheimer: two from mycowood and the other two from untreated wood. A jury of experts, together with the conference participants, judged the tonal quality of the violins. Of the more than 180 attendees, an overwhelming number (90 persons) considered that the tone of the fungally treated violin "Opus 58" to be the best (Table 2). Trusler's Stradivarius reached second place with 39 votes, but, amazingly, 113 members of the audience thought that "Opus 58" was actually the Strad! "Opus 58" was made from wood that had been treated with fungus for the longest time, 9 months. In comparison with the untreated wood instruments, the violins made of mycowood had a warmer, more rounded sound. Many participants at the Osnabrücker Baumpflegetage stressed that the high notes of the untreated violins are irritating on the ear, unpleasant, and shrill, whereas these high notes of the treated wood violins were dampened and the violins sounded more mellow and warmer.

The quality of the resonance wood is very important for the acoustic quality of the violin. The method described here for modifying wood is intended primarily to allow better solo instruments to be made. A solo violinist prefers an instrument that is suitable for playing "against" the orchestra. Its tonal properties include high projection ability, high volume and dynamic range, together with a sensitive modulation of tonal colors. These properties directly depend on the material quality of the resonance plates of the violin. This quality correlates positively with the velocity of the longitudinal sound waves (both across and along the grain) and negatively with wood density. A material with a high ratio of sound velocity to density increases the sound emission of the instrument, which means that the plate amplitudes are high in relation to the force that excites the strings. This enhancement of resonance makes the difference between a violin of average quality and one that is suitable for a top soloist. Future acoustic instruments, made from wood modified by the described procedure, are desirable because of the enormous size of today's concert halls and the needs of soloists.

Instead of seeing the forest as a mass source of low-grade pulp wood that yields only a few US dollars per cubic meter, the trees can be nurtured to their highest potential, where a single violin top (a piece of wood $2.5 \mathrm{~cm}$ thick, $6 \mathrm{~cm}$ wide, and $35 \mathrm{~cm}$ long) can command a price of hundreds of US dollars. That same piece of wood, after leaving the hands of a skilled violin maker, may then be priced in the many thousands of US dollars. Admittedly, not all trees will measure up to these standards, and a large forest industry cannot rely on the demand from violin makers alone. But the point is that it is the highest possible potential of the forest that should be kept in mind as the guiding principle of forest stewardship, not necessarily the most immediate short-term liquidation of the resource, which seems to have been the objective of much of the forest policy of the past.

The mycowood method described here allows improvement in the acoustic properties of resonance wood at a time when it is becoming increasingly difficult to find naturally grown, superior-quality resonance wood because of the impact of global warming. For the professional musician, a violin or cello made in northern Italy's Cremona is the ultimate status symbol. Prices can run as high as US $\$ 27,000$ for a violin, double for a cello. As with other crafts in Europe, lutherie is coming under threat from inexpensively made Chinese products. Xiqiao in southeast China has more than 40 companies turning out a violin, bow and case for US \$25. The Taixing Fengling Musical Instrument Co., one of the largest, made 300,000 violins, violas, cellos, and basses in 2009. To compete, Cremona and other European violin makers must compete on quality. The estimated costs for the production of mycowood (i.e., for a top and bottom plate) are currently approximately US $\$ 2,500$. Thus the mycowood technology meets the economic criteria and enables acoustically superior instruments with same tonal quality to be available to talented young musicians who would never be able to afford their own Stradivarius.
Table 2 Number of votes given for different violins by the attendees at Osnabrücker Baumpflegetage 2009

\begin{tabular}{|c|c|c|c|c|c|}
\hline Violin & $\begin{array}{l}\text { Opus } 55 \\
\text { Untreated }\end{array}$ & $\begin{array}{l}\text { Opus } 56 \\
6 \text {-month treatment }\end{array}$ & $\begin{array}{l}\text { Opus } 58 \\
\text { 9-month treatment }\end{array}$ & Stradivari & $\begin{array}{l}\text { Opus } 54 \\
\text { Untreated }\end{array}$ \\
\hline \multicolumn{6}{|c|}{ Which violin did you like best? } \\
\hline No. of votes & 9 & 24 & 90 & 39 & 19 \\
\hline \multicolumn{6}{|c|}{ Which violin was the Stradivari? } \\
\hline No. of votes & 3 & 15 & 113 & 25 & 17 \\
\hline
\end{tabular}


These studies have sparked the worldwide interest of the media, music lovers, and violin makers. A number of companies that produce acoustic panels and resonance wood suppliers are interested in using wood decay fungi to improve the acoustic properties of wood, which will revolutionize the use of wood in traditional musical instrument making of guitars, violas, hammered dulcimers, acoustic panels, and/or wood cones for loud speakers. The appreciation of wood in the world of acoustics and sounds will continue to increase. Thus, wood can improve its competitive edge over synthetic materials such as carbon fibers that are increasingly being used in musical instrument making. Further studies are currently in progress with the objective of developing a quality assurance program to maximize the probability that minimum standards of quality are being attained by the mycowood process.

Acknowledgments We gratefully acknowledge the close collaboration with following partners: BASF AG, Switzerland; International Speciality Products ISP AG, Baar, Switzerland; Böhme AG-The Wood Care Company, Liebefeld, Switzerland; Bois Ril SA, Palézieux, Switzerland; and the University of Applied Sciences HEV, Sion, Switzerland. Moreover, we express our gratitude to the CTI (Swiss Innovation Promotion Agency, grant No. 8593.1) and Swiss National Science Foundation (grant No. 205321-121701) for their sustained funding.

\section{References}

Anagnost SE (2007) Wood in the built environment: conditions for mold and decay. In: Yang CS, Heinsohn P (eds) Sampling and analysis of indoor microorganisms. Wiley, Hoboken, pp 155-178

Baldrian P (2006) Fungal laccases: occurrence and properties. FEMS Microbiol Rev 30:215-242

Barlow CY, Edwards PP, Millward GR, Raphael RA, Rubio DJ (1988) Wood treatment used in Cremonese instruments. Nature 332:313

Begerow D, Nilsson H, Unterseher M, Maier W (2010) Current state and perspectives of fungal DNA barcoding and rapid identification procedures. Appl Microbiol Biotechnol 87:99-108

Bauch J, Liese W, Berndt H (1970) Biological investigations for the improvement of the permeability of softwoods. Holzforschung 24:199-205

Bruce A, Highley TL (1991) Control of growth of wood decay basidiomycetes by Trichoderma spp. and other potentially antagonistic fungi. Forest Prod J 41:63-67

Bucur V (2006) Acoustics of wood, 2nd edn. Springer, Berlin, Springer Series in Wood Science

Burckle L, Grissino-Mayer HD (2003) Stradivaris, violins, tree rings, and the Maunder Minimum: a hypothesis. Dendrochronologia 21:41-45

Cerniglia CE (1997) Fungal metabolism of polycyclic aromatic hydrocarbons: past, present and future applications in bioremediation. J Ind Microbiol Biotechnol 19:324-333

Claus H (2003) Laccases and their occurrence in prokaryotes. Arch Microbiol 179:145-150

Deflorio G, Hein S, Fink S, Spiecker H, Schwarze FWMR (2005) The application of wood decay fungi to enhance annual ring detection in three diffuse-porous hardwoods. Dendrochronologia 22:123-130

Dill I, Kraepelin G (1986) Palo podrido: model for extensive delignification of wood by Ganoderma applanatum. Appl Environ Microbiol 52:1305-1312
Esper J, Cook ER, Schweingruber FH (2002) Low-frequency signals in long tree-ring chronologies for reconstructing past temperature variability. Science 295:2250-2252

Fuhr M, Stührk C, Schwarze FWMR, Schubert M, Herrmann HJ (2010) Modelling hyphal growth of the bioincising fungus Physisporinus vitreus. In: International Research Group on Wood Preservation, IRG/WP. Biarritz, France, pp 10-710

Graddy K, Margolis P (2010) Fiddling with value: violins as an investment? Econ Inq. doi:10.1111/j.1465-7295.2010.00269.x

Griffin DM (1977) Water potential and wood-decay fungi. Annu Rev Phytopathol 15:319-329

Gug R (1991) Choosing resonance wood. Strad 102:60-64

Hernandez R, Winandy JE (2005) Evaluation of a reduced section modulus model for determining the effects of incising on bending strength and stiffness of structural lumber. Forest Prod J 55:57-65

Highley TL (1997) Control of wood decay by Trichoderma (Gliocladium) virens. I. Antagonistic properties. Mater Org 31:79-89

Highley TL, Padmanabha HSA, Howell CR (1997) Control of wood decay by Trichoderma (Gliocladium) virens. II: antibiosis. Mater Org 31:157-166

Ihssen J, Schubert M, Schwarze FWMR, Thöny-Meyer L (2011) Efficient production of $\mathrm{Al}(\mathrm{OH})_{3}$-immobilized laccase with a Heterobasidion annosum strain selected by microplate screening. J Appl Microbiol 110:924-934

Johnson BR (1979) Permeability changes induced in three western conifers by selective bacterial inoculation. Wood Fiber 11:10-21

Kirk TK, Schultz E, Connors WJ, Lorenz LF, Zeikus JG (1978) Influence of culture parameters on lignin metabolism by Phanerochaete chrysosporium. Arch Microbiol 117:277-285

Kudanga T, Prasetyo EN, Sipila J, Eberl A, Nyanhongo GS, Guebitz GM (2009) Coupling of aromatic amines onto syringylglycerol betaguaiacylether using Bacillus SF spore laccase: a model for functionalization of lignin-based materials. J Mol Catal B Enzym 61:143-149

Lehringer C (2011) Permeability improvement of Norway spruce wood with the white rot fungus Physisporinus vitreus. $\mathrm{PhD}$ thesis, Georg-August-University, Göttingen. http://webdoc.sub. gwdg.de/diss/2011/lehringer/lehringer.pdf

Lehringer C, Arnold M, Richter K, Schubert M, Schwarze FWMR, Militz H (2009) Bioincised wood as substrate for surface modifications. In: Englund F, Hill CAS, Militz H, Segerholm BK (eds) Proceedings of the European conference on wood modification, Stockholm, pp 197-200

Lehringer C, Hillebrand K, Richter K, Arnold M, Schwarze FMWR, Militz H (2010) Anatomy of bioincised Norway spruce wood. Int Biodeterior Biodegrad 64:346-355

Lehringer C, Koch G, Adusumalli R-B, Mook WM, Richter K, Militz $\mathrm{H}$ (2011) Effect of Physisporinus vitreus on wood properties of Norway spruce. Part 1: aspects of delignification and surface hardness. Holzforschung. doi:10.1515/HF.2011.021

Levi MP, Cowling EB (1969) Role of nitrogen in wood deterioration. VII: physiological adaptation of wood-destroying and other fungi to substrates deficient in nitrogen. Phytopathology 59:460-468

Mai C, Kües U, Militz H (2004) Biotechnology in the wood industry. Appl Microbiol Biotechnol 63:477-494

Majcherczyk A, Hüttermann A (1988) Bioremediation of wood treated with preservative using white-rot fungi. In: Bruce A, Palfreyman JW (eds) Forest products biotechnology. Taylor and Francis, London, pp 129-140

Messner K, Fackler K, Lamaipis P, Gindl W, Srebotnik E, Watanabe T (2002) Biotechnological wood modification. In: Proceedings of the international symposium on wood-based materials, part 2. Vienna University, pp 45-49

Meyer HG (1995) A practical approach to the choice of tone wood for the instruments of the violin family. Catgut Acoust Soc J 2:9-13

Meyer V (2008) Genetic engineering of filamentous fungi: progress, obstacles and future trends. Biotechnol Adv 26:177-185 
Militz H (1993a) Der Einfluss enzymatischer Behandlungen auf die Tränkbarkeit kleiner Fichtenproben. Holz Roh Werkst 51:135-142

Militz H (1993b) Der Einfluss enzymatischer Behandlungen von Fichtenrund-und Schnittholz zur Verbesserung der Tränkbarkeit. Holz Roh Werkst 51:339-346

Nagyvary J (1988) Chemistry of Stradivarius. Chem Eng News 66:24-31

Nagyvary J, DiVerdi JA, Owen NL, Tolley HD (2006) Wood used by Stradivari and Guarneri. Nature 444:565

Nicholas DD, Thomas RJ (1968) The influence of enzymes on the structure and permeability of loblolly pine. Proc Am Wood Preserv Assoc 64:70-76

Nilsson T, Daniel G, Kirk K, Obst JR (1989) Chemistry and microscopy of wood decay by some higher Ascomycetes. Holzforschung 43:11-18

Ono T, Norimoto M (1984) On physical criteria for the selection of wood for soundboards of musical instruments. Rheol Acta 23:652-656

Rayner ADM, Boddy L (1988) Fungal decomposition of wood: its biology and ecology. Wiley, Chichester

Reid ID (1983) Effects of nitrogen supplements on degradation of aspen wood lignin and carbohydrate components by Phanerochaete chrysosporium. Appl Environ Microbiol 45:830-837

Richter DL, Warner JI, Stephens AL (2003) A comparison of mycorrhizal and saprotrophic fungus tolerance to creocote. Int Biodeterior Biodegrad 51:195-202

Ruiz-Diez B (2002) Strategies for the transformation of filamentous fungi. J Appl Microbiol 92:189-195

Samson J, Langlois É, Lei J, Piché Y, Chênevert R (1998) Removal of 2,4,6-trinitrotoluene and 2,4-dinitrotoluene by fungi (Ceratocystis coerulescens, Lentinus lepideus and Trichoderma harzianum). Biotechnol Lett 20:355-358

Schleske M (1998) On the acoustical properties of violin varnish. Catgut Acoust Soc J 3:15-24

Schleske M (2002a) Empirical tools in contemporary violin making: part I. Analysis of design, materials, varnish and normal modes. Catgut Acoust Soc J 4:50-64

Schleske M (2002b) Empirical tools in contemporary violin making: part II: psychoacoustic analysis and use of acoustical tools. Catgut Acoust Soc J 4:83-92

Schmidt O (2007) Indoor wood-decay basidiomycetes: damage, causal fungi, physiology, identification and characterization, prevention and control. Mycol Prog 6:261-279

Schmidt O, Liese W, Moreth U (1996) Decay of timber in a water cooling tower by the basidiomycete Physisporinus vitreus. Mater Org 30:161-177

Schmidt O, Schmitt U, Moreth U, Potsch T (1997) Wood decay by the white-rotting basidiomycete Physisporinus vitreus from a cooling tower. Holzforschung 51:193-200

Schubert M, Schwarze FWMR (2011) Evaluation of the interspecific competitive ability of the bioincising fungus Physisporinus vitreus. J Basic Microbiol 51:80-88

Schubert M, Dengler V, Mourad S, Schwarze FWMR (2009a) Determination of optimal growth parameters for the bioincising fungus Physisporinus vitreus by means of response surface methodology. J Basic Microbiol 106:1734-1742

Schubert M, Mourad S, Fink S, Schwarze FWMR (2009b) Ecophysiological responses of the biocontrol agent Trichoderma atroviride (T15603.1) to combined environmental parameters. Biol Control 49:84-90

Schubert M, Mourad S, Schwarze FWMR (2010a) Radial basis function neural networks for modeling growth rates of the basidiomycetes Physisporinus vitreus and Neolentinus lepideus. Appl Microbiol Biotechnol 85:703-712

Schubert M, Mourad S, Schwarze FWMR (2010b) Statistical approach to determine the effect of combined environmental parameters on conidial development of Trichoderma atroviride (T-15603.1). J Basic Microbiol 50:570-580

Schubert M, Volkmer T, Lehringer C, Schwarze FWMR (2011a) Resistance of bioincised wood treated with wood preservatives to blue-stain and wood-decay fungi. Int Biodeterior Biodegrad 65:108-115

Schubert M, Mourad S, Schwarze FWMR (2011b) Automated image processing for quantification of blue-stain discolouration of Norway spruce wood. Wood Sci Technol 45:331-337

Schwarze FWMR (1995) Entwicklung und biomechanische Auswirkungen von holzzersetzenden Pilzen in lebenden Bäumen und in vitro. PhD thesis, Albert-Ludwigs-Universität Freiburg, Germany

Schwarze FWMR (2007) Wood decay under the microscope. Fungal Biol Rev 21:133-170

Schwarze FWMR (2008) Diagnosis and prognosis of the development of wood decay in urban trees. ENSPEC, Melbourne

Schwarze FWMR, Landmesser H (2000) Preferential degradation of pit membranes within tracheids by the basidiomycete Physisporinus vitreus. Holzforschung 54:461-462

Schwarze FWMR, Engels J, Mattheck C (2004) Fungal Strategies of Wood Decay in Trees. Springer Verlag, Heidelberg

Schwarze FWMR, Spycher M, Fink S (2008) Superior wood for violins - wood decay fungi as a substitute for cold climate. New Phytol 179:1095-1104

Schwarze FWMR, Landmesser H, Zgraggen B, Heeb M (2006) Permeability changes in heartwood of Picea abies and Abies alba induced by incubation with Physisporinus vitreus. Holzforschung 60:450-454

Sharma M, Kumar S (1979) Degradation of wood pectin bymicroorganisms. Int J Wood Preserv 1:87-90

Shuen SK, Buswell JA (1992) Effect of lignin derived phenols and their methylated derivatives on the growth of Lentinus spp. Lett Appl Microbiol 15:12-14

Spycher M, Schwarze FWMR, Steiger R (2008) Assessment of resonance wood quality by comparing its physical and histological properties. Wood Sci Technol 42:325-342

Stührk C, Fuhr M, Schubert M, Schwarze FWMR (2010) Analyzing hyphal growth of the bioincising fungus Physisporinus vitreus with light-, confocal laser scanning- and synchrotron X-ray tomographic microscopy. In: International Group on Wood Preservation, IRG 1020438, Biarritz, France

Tschernitz JL (1973) Enzyme mixture improves creosote treatment of kiln-dried Rockey Mountain Douglas-fir. Forest Prod J 23:30-38

Topham TJ, McCormick MD (2000) A dendrochronological investigation of stringed instruments of the Cremonese School (16661757) including "The Messiah" violin attributed to Antonio Stradivari. J Archaeol Sci 27:183-192

Unbehaun H, Dittler B, Kuhne G, Wagenfuhr A (2000) Investigation into the biotechnological modification of wood and its application in the wood-based material industry. Acta Biotechnol 20:305-312

Van Acker J, Stevens M, Rijckaert V (1995) Highly virulent woodrotting basidiomycetes in cooling towers. In: International Research Group on Wood Preservation, IRG/WP/95-10125, Ghent

Wagenführ A, Pfriem A, Eichelberger K (2005a) Der Einfluss einer thermischen Modifikation von Holz auf im Musikintrumentenbau relevante Eigenschaften. Teil I: Spezielle Anatomische und Physikalische Eigenschaften. Holztechnologie 46:36-42

Wagenführ A, Pfriem A, Eichelberger K (2005b) Der Einfluss einer thermischen Modifikation von Holz auf im Musikinstrumentenbau relevante Eigenschaften. Teil 2: Technologische Eigenschaften, Herstellung und Prüfung von Musikinstrumentenbauteilen. Holztechnologie 47:39-43

Wegst UGK (2006) Wood for sound. Am J Bot 93:1439-1448

Yano H, Kajita H, Minato K (1994) Chemical treatment of wood for musical instruments. J Acoust Soc Am 96:3380-3391 